\title{
The Interface Between Quality and Violence in Marital Relationships ${ }^{1}$
}

\author{
Josiane Razera ${ }^{2}$ \\ Universidade do Vale do Rio dos Sinos, \\ São Leopoldo-RS, Brazil \\ Clarisse Pereira Mosmann \\ Universidade do Vale do Rio dos Sinos, \\ São Leopoldo-RS, Brazil \\ Denise Falcke \\ Universidade do Vale do Rio dos Sinos, \\ São Leopoldo-RS, Brazil
}

\begin{abstract}
Domestic violence has been considered accountable for a reduction in the level of marital quality, although no relationship has been identified between these variables. This study aimed to measure the levels of marital quality and domestic violence, as well as their relationship with sociodemographic characteristics and the predictive power of the different types of violence on martial quality. This quantitative study included 186 heterosexual couples $(N=372)$, who answered a sociodemographic questionnaire, the Golombok Rust Inventory of Marital State (GRIMS), and the Revised Conflict Tactics Scales (CTS2). The respondents assessed their marital quality as being average or very good (66.5\%), and poor or with very severe problems $(33.5 \%)$. Although good levels of marital quality prevailed, the rates of psychological violence reached $86.6 \%$. A negative correlation was found between violence and marital quality. A possible naturalization of violence was found, especially psychological, which was the dimension with the highest predictive power for marital problems.
\end{abstract}

Keywords: family violence, marital relations, quality indicator

\section{A Interface Entre a Qualidade e a Violência em Relacionamentos Conjugais}

\begin{abstract}
Resumo: A violência conjugal tem sido apontada como responsável pela redução dos níveis de qualidade conjugal, porém outros estudos identificam independência entre essas variáveis. O objetivo deste estudo foi mensurar os níveis de qualidade e violência conjugal, bem como a relação com características sociodemográficas e o poder preditivo dos diferentes tipos de violência na qualidade conjugal. Participaram deste estudo quantitativo, 186 casais heterossexuais $(N=372)$ que responderam um questionário sociodemográfico, o Golombok Rust Inventory of Marital State (GRIMS) e o Revised Conflict Tactics Scales (CTS2). Dos participantes, $66,5 \%$ avaliaram a qualidade conjugal entre média e muito boa e 33,5\% entre pobre a problemas muito severos. Ainda que tenham preponderado bons níveis de qualidade conjugal, os índices de violência psicológica chegaram a 86,6\%. Houve correlação negativa entre violência e qualidade conjugal. Verifica-se uma possível naturalização da violência nos relacionamentos, especialmente a psicológica, que foi a dimensão com maior poder preditivo de problemas na conjugalidade.
\end{abstract}

Palavras-chave: violência na família, relações conjugais, indicadores de qualidade

\section{Una Interfaz Entre la Calidad y la Violencia en Relaciones Maritales}

\begin{abstract}
Resumen: La violencia marital ha sido asociada a la reducción de niveles de calidad marital, pero otros estudios identifican independencia entre esas variables. Se objetivó mensurar niveles de calidad y violencia marital, la relación con características sociodemográficas y el poder predictivo de diferentes tipos de violencia en la calidad marital. En este estudio cuantitativo participaron 186 parejas heterosexuales $(N=372)$. Los instrumentos fueron: cuestionario sociodemográfico, GRIMS (Golombok Rust Inventory of Marital State) y CTS2 (Revised Conflict Tactics Scales). De los participantes, 66,5 \% valoró la calidad marital entre media y muy buena y el 33,5\% desde pobre a problemas muy graves. Aunque han preponderado buenos niveles de calidad marital, las tasas de violencia psicológica han alcanzado el 86,6\%. Fue encontrada correlación negativa entre violencia y calidad marital. Hay una posible naturalización de la violencia en las relaciones, especialmente la psicológica, que ha tenido un mayor poder predictivo de problemas matrimoniales.
\end{abstract}

Palabras clave: violencia doméstica, relaciones conyugales, indicadores de calidad

Intimate relationships are associated with key aspects in peoples' lives, therefore they can be healthy for those

\footnotetext{
${ }^{1}$ Article derived from the first author's master's thesis, under supervision of the third author, defended in 2014 in the Graduate Program in Psychology at Universidade do Vale do Rio dos Sinos - UNISINOS.

Support: National Council for Scientific and Technological Development and Coordination for the Improvement of Higher Education Personnel (CNPq/CAPES, Edital Human Sciences, Protocol No. 401663/2011-6).

${ }^{2}$ Correspondence address:

Josiane Razera. Rua Jacinto Villa Nova, ${ }^{\circ}$ 179, apto 1103, Centro. CEP 99010-290. Passo Fundo-RS, Brazil. E-mail: josianerazera@yahoo.com.br
}

involved, or they can cause emotional, psychological and even physical damage, in the case of a dysfunctional relationship. Beginning with the second half of the twentieth century, studies on marriage intensified, given the need to understand the dynamics of marital functioning, evaluating aspects related to relationships that provide satisfaction to couples to relationships that generate violence and health hazards (Carvalho-Barreto, Bucher-Maluschke, Almeida, \& DeSouza, 2009; D’Oliveira, Schraiber, Hanada, \& Durand, 2009).

Because marital satisfaction comprises difficult and subjective analyses, confusion is noted regarding the use 
of terms observed in the literature (De Andrade \& Garcia, 2012; Graham, Diebels, \& Barnow, 2011), with quality and marital satisfaction often used interchangeably. Because there are different concepts, the concept proposed by Mosmann, Wagner and Féres-Sheep (2006) was used in the present study, with marital quality understood as being multidimensional, with marital satisfaction or happiness being considered one of its dimensions. The authors found that the perception of marital quality is associated with three dimensions: (a) spouses' personal resources, i.e., educational levels, personality aspects, family experiences and others; (b) the context of the spouses, i.e., stressors, which can be related to illness, financial difficulties, and others; (c) adaptive processes, i.e., the capacity of confronting difficulties encountered by the spouses and adapting to them. Marital quality can manifest in different intensities, from very high levels of marital quality to very severe problems in the relationship (Rust, Bennun, Crowe, \& Golombok, 1986). Although the term marital quality was chosen, throughout the text the terms are used interchangeably, thereby respecting the different authors' concept choices.

In this context, marital quality can be understood as a comprehensive construct, since the relationships can be evaluated by couples as good in terms of quality of the relationship, although the person is not satisfied, because there are other dimensions that make up marital quality. Satisfaction can be understood as a subjective evaluation of the relationship, a result obtained after comparison of their wedded life with marriage expectations, arising from early experiences and social and cultural issues (Rizzon, Mosmann, \& Wagner, 2013).

From this perspective, one can consider that satisfaction is associated with conscious and unconscious aspects, as well as environment aspects and aspects from the context in which the spouses are integrated (Mosmann et al., 2006). It is possible to think that some factors, such as emotional closeness, communication, conflict resolution strategies, shared values, and religious beliefs can be associated with the increase or decrease in satisfaction in the relationship (Rebello, Junior, $\&$ Brito, 2014). The marital satisfaction of 106 participants was assessed by Scorsolini-Comin and Santos (2010), who found no association with the age of the spouses, length of the relationship, income, or educational level.

Making statements and evaluations of the marital quality levels is complex, especially when the spouse is understood systemically because, as mentioned by Féres-Sheep and Diniz Neto (2010), spouses are integrated in varying levels of other relationships and psychosocial contexts that will be present in the constitution of the relationship. Each partner brings characteristics of his/her individuality to the marriage, and it is through the sum of these characteristics that the marital identity of the new couple is created.

Couples with higher levels of functionality have theoretically demonstrated stable characteristics, similar tastes, common interests and projects, and their differences enrich the relationship (Scorsolini-Comin \& Santos, 2010). However, when flaws are observed, such as in companionship, communication or joint planning, conflicts arise that need to be negotiated. Marital disagreements, whether emotional, sexual or economic, can result in high levels of marital conflict (Carvalho-Barreto et al., 2009). However, it is important to highlight that marital functionality is not associated with the existence or nonexistence of conflicts, but with the way couples manage them. Aggression and attacks are inadequate conflict resolution strategies that are often used by dysfunctional couples (Falcke, Wagner, \& Mosmann, 2013). Currently, the literature indicates that among interpersonal violence, intimate partner violence is considered one of the major global health problems (Carvalho-Barreto et al., 2009; D'Oliveira et al., 2009; Moreira, Galvão, Melo, \& Azevedo, 2008).

A relationship with violence tends to be detrimental, not only to spouses, but also to other people in their family and social circles (Carvalho-Barreto et al., 2009). Anacleto, Njaine, Long, Boing and Peres (2009) defined domestic violence as an interactive phenomenon that involves both men and women as perpetrators or victims. Every couple has different characteristics, and domestic violence cannot be evaluated without considering the situational and demographic aspects. Vieira, Perdona, and Santos (2011), in a study with 504 women, presented some variables that are risk factors for the occurrence of physical violence in the marital relationship, namely: low educational level, marital status (being separated or cohabiting), having experienced or witnessed violence in childhood, and alcohol use. In contrast, violence was not associated with age, race or religion.

Regarding the studies on marital violence, the view that there is a gender asymmetry is predominant. This can be considered a reflection of the feminist movement that has denounced the abuses and mistreatment to women by their intimate partners. It is common to find authors who advocate in favor of women, in a one-sided view which places women in a victim role. On the other hand, psychologists and family sociologists study couple violence or violence as an interactional process (Falcke \& Féres-Carneiro, 2011).

From this perspective, violence is characterized as a dynamic action constructed by spouses, who are co-authors of marital functioning (Falcke \& Féres-Carneiro, 2011; Falcke, Oliveira, Rosa, \& Bentancur, 2009). In Williams and Frieze's studies (2005), conducted in the state of Michigan, more women reported committing violence than men, which led the authors to point out that individuals are mutually violent and that they sometimes use violence as a form of protection. A study by Mosmann and Falcke (2011) with 149 couples found significant levels of misunderstanding and aggression. The accumulation of conflicts which had not be solved by the couple became a cyclical process, favoring disagreements which returned later in a stronger manner. In addition, many couples did not recognize that the strategies used in an attempt to resolve marital conflicts included forms of physical and, especially, psychological violence. All these data indicate the importance of relational evaluation of the violent couple (Cortez, Souza, \& Queiroz, 2010) for planning interventions to be performed with these couples, assuming that violence occurs due to the dynamic established between them.

Relationships based on some form of violence can compromise the levels of quality in the marital relationship. 
Lawrence and Bradbury (2007) conducted a longitudinal study with 172 American couples, and pointed out that initial levels of aggression can cause changes in marital satisfaction, whereas initial levels of satisfaction do not predict changes in aggression. They further suggested that there is a vicious cycle wherein aggression leads to the decline of marital satisfaction, which in turn leads to increased aggression, and so on. It is also necessary to point out that although some authors state that satisfaction with the relationship is impacted by domestic violence (Hellmuth \& McNulty, 2008; Lawrence \& Bradbury, 2007; Testa \& Leonard, 2001 ), the possibility of violence occurring as a consequence of dissatisfaction with the relationship is not ruled out (DeMaris, 2000; Williams \& Frieze, 2005).

On the other hand, studies have shown that intimate partner violence will not necessarily result in decreased marital quality. Follingstad, Rogers, and Duvall (2012) investigated a sample of 361 North American women, and found that those who utilized psychological violence tactics to solve conflicts showed higher levels of marital satisfaction. In addition, women who also used some form of aggression in the relationship tended to report less marital dissatisfaction than those who saw aggression as one-sided. Williams and Frieze (2005) reported that some people were considered relatively satisfied with their relationship, even though it was a violent relationship, while others in the same study reported less satisfaction and that violence was a form of self-protection. Again, it was evident that satisfaction levels can exist in a violent relationship, which included the fact that the aggression is not always taken seriously.

The existence of a difference in satisfaction levels between men and women in a violent relationship was analyzed by Ackerman (2012), from a gender perspective. Men reported less dissatisfaction, whereas women felt more affected by violent relationships and reported lower levels of marital quality. The authors explained these findings by adopting the perspective that, for men, it would be easier to maintain a loving relationship with aggressive women, whereas the opposite would be more difficult. It is socially acceptable that women assume the weak, victim position, a role that is not understood if performed by males. Similar data had been highlighted by DeMaris (2000) in a sample of 3,508 American couples, which found that the perpetration of domestic violence by men increased the risk of divorce, whereas the perpetration of violence by women did not have the same effect.

In this context, there are differences in the results of international studies on marital quality in couples with violent functioning. In terms of the Brazilian literature, using the descriptors of domestic violence and marital quality, no studies were found correlating these variables (Scielo, BVS, LILACS). Due to these reasons, the aim of this study is to investigate the association between marital quality and domestic violence. The specific objectives were to measure the levels of violence and marital quality in domestic violence, to relate the levels of quality and violence with sociodemographic characteristics of the couples, and to identify the predictive power of the different types of violence in marital quality.

\section{Method}

A quantitative, descriptive, correlational and explanatory study was performed (Hernández Sampieri, Fernández Collado, \& Baptista Lucio, 1998/2013). This study is part of a larger project entitled, "Predictive variables of domestic violence: family experiences, personal and relational characteristics", which aimed to investigate the predictive power of family experiences, the couple's personality, and the couple's characteristics on the occurrence of violence in the marital relationship.

\section{Participants}

One hundred eighty-six individuals and their spouses participated in this study, totaling 372 . It was a convenience sample, based on nomination by acquaintances, and based on the suggestion of the participants themselves, thus constituting a snowball sample. The participants in the data collection period (August 2013 to August 2014) were residing in the metropolitan area of Porto Alegre, RS. The inclusion criteria were: in a heterosexual marriage relationship, and married for a minimum period of six months. There were no exclusion criteria.

As sample characteristics, it was observed that the age of the participants ranged from 19 to 81 years $(M=39.92$, $S D=12.62)$ and the duration of relationships ranged from one to 56 years $(M=14.81 ; S D=11.69)$. Education was distributed as follows: no education $(0.6 \%)$, elementary education (8.6\%), secondary education (41.4\%), and higher education in progress or completed $(49.4 \%)$. The monthly personal income was zero to 45,000 reais per month $(M=$ $3541.98, S D=4218.23$ ). Of the total, $56.7 \%$ were officially married and $43.3 \%$ were living together. In addition, $79.6 \%$ had been previously married.

\section{Instruments}

Socio-Demographic Data Questionnaire. Composed of 19 questions to collect data such as: gender, age group, education, whether they have children and how many, marital status, time since engagement, personal income, whether they lived with their biological parents during their childhood, and the marital situation of their parents. Other information, such as religiosity of the participants and whether they had been through some type of psychotherapy, was also collected.

Golombok Rust Inventory of Marital State - GRIMS (Rust et al., 1986). An inventory that measures the quality of the marital relationship through aspects that are considered important to a good marriage, namely: satisfaction, communication, shared interests, trust and respect. It is a self-administered instrument, consisting of 28 items on a four-point Likert scale (strongly disagree, disagree, agree and strongly agree). In the scale, the higher the scores, the more severe the problems in the marital relationship. In this study, the alpha was .889 , which is considered very good (Hernández Sampieri et al., 1998/2013).

Revised Conflict Tactics Scales - CTS2. It was conceived by Straus, Hamby, Boney-McCoy, and Sugarman (1996), 
and adapted to Portuguese by Moraes, Hasselmann, and Reichenheim (2002). The scale contains 78 items that describe possible actions of the respondent and, conversely, of his/her spouse. It consists of five scales that address the following dimensions: (a) physical violence, (b) psychological abuse, (c) sexual coercion, (d) bodily injury, and (e) negotiation. Physical violence is defined by the authors as minor (pushing, grabbing, slapping, throwing objects, twisting the arm, pulling the hair) and severe (punching, hitting, kicking, throwing against the wall, burning or scalding, using a knife or a firearm). Minor psychological aggression is defined as insults, curses, screaming, calling names, threats and turning one's back during a fight, whereas severe psychological aggression corresponds to calling names (calling the partner ugly, fat, bad in bed or something similar, destroying the spouse's personal belongings). Minor sexual coercion refers to an insistence on having sex without using physical force, or forcing the partner to have sex without a condom, while severe sexual coercion corresponds to threatened actions or use of force and weapons to coerce partners to have sex. Minor bodily injury corresponds to the occurrence of a twist, contusion, bruise or body ache that lasts until the next day due to a fight, while severe bodily injury refers to the need to seek medical aid due to a fight, fainting, or breaking a bone.

In this study, the alpha of the total CTS2 scale was .872, and the alpha for each subscale was: severe - performed sexual coercion (.796); severe - suffered sexual coercion (.825); minor - performed sexual coercion (.321); minor - suffered sexual coercion (.344); severe - performed physical violence (.858); severe - suffered physical violence (.769); minor - performed physical violence (.772); minor suffered physical violence (.826); severe - performed bodily injury (.522); severe - suffered bodily injury (.819); minor - performed bodily injury (.596); minor - suffered bodily injury (.586); severe - performed psychological aggression (.330); severe - suffered psychological aggression (.444); minor - performed psychological aggression (.698); minor suffered psychological aggression (.684). The alphas ranged from reasonable to very good (Hernández Sampieri et al., 1998/2013).

\section{Procedure}

Data collection. The questionnaires were administered by research assistants (undergraduate research fellows, and master's and doctoral students) at the homes of the couples or in a place indicated by them; they were scheduled in advance by telephone. During data collection, the study objectives were explained and the Informed Consent (IC) was signed, which also aimed to ensure the confidentiality and anonymity of the respondents. Then, the questionnaire was administered to the couple concurrently, without either having access to the responses of the other, thereby avoiding contamination of individual responses.

Data analysis. Data were analyzed using the Statistical Package for the Social Sciences software - SPSS (version 20.0). Descriptive analyses were performed to identify the participants' profile, the percentage of domestic violence, and marital quality. After confirmation of the data distribution parameters of normality (Kolmogorov-Smirnov test), Pearson's correlation analysis, $t$ test, ANOVA and stepwise regression analysis were used, according to the aims of the study.

\section{Ethical Considerations}

This study was approved by the Ethics Committee of Universidade do Vale do Rio dos Sinos under protocol no. 11/129, on September 27, 2011, and abided by all the guidelines and regulatory standards for research involving human beings.

\section{Results}

\section{Marital Quality}

By using GRIMS, it was possible to measure how couples perceived the quality of their marital relationship. Most participants referred to the marriage as being between average to very good $(66.54 \%$ ), whereas $33.47 \%$ evaluated the relationship as being between poor to very severe problems.

Considering the sociodemographic variables, marital quality was not found to be significantly different according to gender $(t=-0.518 ; p=.605)$ or marital status $(t=1.328$, $p=.185)$. Marital quality was also not associated with age $(r=.013 ; p=.828)$, length of relationship $(r=.054 ; p=$ $.354)$, or the couples' income ( $r=-.018 ; p=.772)$.

To evaluate the behavior of the education variable, ANOVA was performed considering three groups (elementary, secondary and higher education). There was no statistically significant difference $(F=2.790 ; p=.063)$ in the marital quality of couples with elementary education $(M=29.70$, $S D=10.13)$ compared to couples with secondary education $(M=28.29, S D=11.00)$ or higher education $(M=25.52$, $S D=10.38$ ). It should be noted that in the GRIMS, a higher score refers to more marital problems.

\section{Domestic Violence}

The rates of different types of performed violence (when the respondent evaluates his/her own actions) and suffered violence (when the respondent evaluates the actions of his/her partner) were evaluated. The levels of violence in this sample range from $1.0 \%$ with severe sexual coercion to $86.6 \%$ with minor psychological aggression; $25.9 \%$ of women and $16.1 \%$ of men reported having performed severe psychological aggression. On the other hand, $25.8 \%$ of men and $21.8 \%$ of women reported performing minor physical violence.

A significant difference in the response of wives and husbands was observed using the Student's t-test in the dimensions of minor sexual coercion and severe psychological aggression. In the dimension of minor sexual coercion, there was a statistically significant difference $(t=4.604, p<.001)$, indicating that men $(M=3.75)$ reported committing minor sexual coercion more frequently when compared to women $(M=3.22)$. A significant difference $(t=2.081, p=.039)$ was 
also found in the severe psychological aggression dimension, with women $(M=3.44)$ reporting that they committed more severe psychological aggression than their spouses $(M=3.26)$. There was no significant difference in minor psychological aggression $(t=1.856, p=.064)$ comparing women $(M=8.63)$ to men $(M=8.09)$. There were no statistically significant differences in the dimensions of severe or minor physical violence, and severe or minor bodily injury $(p>.05)$.

By evaluating the violence that the participants perceived they suffered in the marital relationship, high levels were also found: $85.7 \%$ of women reported having suffered minor psychological aggression from their partners and $83.4 \%$ of men reported the same; $23.0 \%$ of men reported having suffered severe psychological violence from their partners, whereas $21.1 \%$ of women reported the same. Regarding severe sexual coercion, $2.7 \%$ of women and $1.6 \%$ of men reported having suffered this in their relationships. No significant differences in any of the dimensions of suffered violence were found, considering the participants' gender $(p>.05)$.

Considering the remaining sociodemographic variables and their associations with the dimensions of violence performed and suffered by the participants, the $t$-test was used to investigate whether rates differed according to the marital status of the participants. It was possible to observe statistically significant differences $(t=2.209, p=.025)$ in terms of a greater perception of suffering minor sexual coercion in couples living together or in a common-law marriage $(M=3.54)$ compared to those officially married $(M=3.30)$.

Age was negatively correlated with the variables, performed minor physical violence $(r=-.166 ; p=.002)$, suffered minor physical violence $(r=-.138 ; p=.009)$, committed severe psychological aggression $(r=-.148 ; p=$ $.005)$, suffered severe psychological aggression $(r=-.134$; $p=.011)$, and performed minor psychological aggression $(r=$ $-.148 ; p=.006)$. These data are indicative that the younger the age of the spouses, the higher the levels of violence performed and suffered. In addition, there was no significant correlation between age and suffering minor psychological aggression $(r=-.102 ; p=.054)$. The length of relationship also showed no significant association with suffering severe physical violence $(r=-.102 ; p=.058)$ and performing minor physical violence $(r=-.101 ; p=.060)$.

There were no significant differences in levels of violence considering the education of the participants. Regarding the association between income and dimensions of violence, there was a negative correlation with performing severe psychological aggression $(r=-.148 ; p=.005)$. Suffering severe psychological aggression $(r=-.108 ; p=$ $.058)$ and suffering minor sexual coercion $(r=-.108 ; p=$ $.059)$ were not associated.

\section{Correlations Between Marital Quality and Domestic Violence}

Correlations were made between the scales of domestic violence (CTS2) and marital quality (GRIMS); statistically significant but weak to moderate correlations were identified. Table 1 shows these data.

Table 1

Correlations Between the CTS2 and GRIMS Dimensions

\begin{tabular}{llcc}
\hline Dimensions of Performed Violence (CTS2) & GRIMS & Dimensions of Suffered Violence (CTS2) & GRIMS \\
\hline Severe Sexual Coercion & .099 & Minor Sexual Coercion \\
Minor Sexual Coercion & $.139^{*}$ & .110 & $.255^{* *}$ \\
Severe Physical Violence & $.138^{*}$ & $.243^{* *}$ & Severe Physical Violence \\
Minor Physical Violence & $.121^{*}$ & Minor Physical Violence \\
Severe Bodily injury & $.244^{* *}$ & Severe Bodily injury \\
Minor Bodily injury & $.267^{* *}$ & Severe Psychological Aggression \\
Severe Psychological Aggression & $.346^{* *}$ & Minor Psychological Aggression \\
Minor Psychological Aggression & $.257^{* *}$ & $.115^{*}$ \\
\hline
\end{tabular}

Note. Significant correlation at the **.01 and *.05 levels.

There was an association among most of the analyzed dimensions. The correlations were positive with GRIMS, because the highest score in GRIMS refers to the existence of more severe marital problems and lower marital quality. The more violence there is in the marital relationship, the lower the quality perceived by the participants in their relationships.

\section{Predictive Power of Violence on Marital Quality}

From the data correlation, it was found that the occurrence of violence in the marital relationship was related to the decline in marital quality levels. Then a stepwise regression analysis was performed, which identified which 
forms of violence were predictive of marital problems. We opted for the evaluation of models separated by gender, considering that there was a significant difference in sexual coercion and psychological aggression between the genders.

When women were evaluated, they perceived minor psychological aggression from their spouse $(\beta=1.752 ; p<$ $.001)$, which explains $16.5 \%\left(R^{2}=.165\right)$ of the variance in the occurrence of marital problems in relationships. That is, for women, suffering psychological aggression from their spouse favors their perception of a less satisfactory relationship.

From the husbands' perspective, two variables were in the model. Minor psychological aggression $(\beta=1.752 ; p<$ $.001)$ and severe psychological aggression $(\beta=1.752 ; p=$ .023) performed by them had a predictive power of $17.4 \%$ $\left(R^{2}=.174\right)$ of the variance in the occurrence of marital problems. This shows that men see the levels of quality of the marital relationship decrease when they perceive themselves as performing psychological aggression (minor and/or severe) against their partners. Psychological aggression was the dimension with the greatest impact on marital quality for both men and women.

\section{Discussion}

Minor psychological aggression, namely insults, curses, screaming, calling names, threats and/or turning one's back during a fight, has been a tactic used by couples trying to resolve conflicts, albeit dysfunctional, reaching levels that exceed $80 \%$ in this sample. These data confirm the national research presented by Bolze, Schmidt, Crepaldi and Vieira (2013), in which, although most couples considered their relationship to be harmonious, yet they also use minor psychological aggression as the main way to attempt to resolve conflicts. This shows that although couples report resolving their conflicts through dialogue, they also end up using behaviors such as swearing, shouting and threatening in situations of conflict.

Actions involving violence were identified, indicating that men and women are performing and suffering different manifestations of domestic violence. No statistically significant differences in the rates of physical violence and bodily injury were identified when comparing the genders. This indicates that husbands and wives admitted performing physical aggressions at the same frequency and intensity. Therefore, it was found that violent behaviors can arise from both spouses, providing opportunities for a more balanced look at the marital relationship. These findings corroborate national and international studies that indicate that the man is not always the aggressor with the woman as the victim, but an interactional bias prevails (Colossi \& Falcke, 2013; Diniz, Lopes, Gesteira, Alves, \& Gomes, 2003; Follingstad \& Edmundson, 2010; Lamoglia \& Minayo, 2009).

However, with regard to sexual coercion, men are likely to perform it significantly more often than women, whereas psychological aggression was performed significantly more often by the women in this study. Gender bias seems to be evident in this differentiation, marking the focus on sexuality a male characteristic and the focus on the emotional/psychological aspects a female characteristic. Therefore, the data highlight the importance of considering the gender variable in the analysis of violence, understanding that this is a complex phenomenon with multiple forms of expression, and it is culturally influenced. This understanding corroborates national data that emphasize the importance of marital dynamics, but also the social rules that still express themselves in marriage and in the construction of domestic violence (Diniz, 2013).

Minor sexual coercion was significantly more frequent in cohabiting couples than in those who were officially married. This datum refers to other national studies already showing the importance of official marriage. Vieira et al. (2011) found that women who cohabited, or were separated or divorced, were twice as likely to experience partner violence compared to women who were officially married. Thus, it can hypothesized that the wedding ritual is extremely important so that spouses are also emotionally able to formalize the relationship.

Minor sexual coercion and severe suffered psychological aggression were not associated with a lower income in the household. Previous international studies have found an association between socioeconomic issues and domestic marital violence (Koenig, Stephenson, Ahmed, Jejeebhoy, \& Campbell, 2006). In this study, this was not confirmed, however it should be noted that income was fairly homogenous in this sample, which was characterized as socioeconomic classes A, according to the CCBE - Brazilian Socio-Economic Classification Criterion. It is known that violence, whether physical, psychological or sexual, can be present in any social and economic context, but it is pertinent to consider that in less favorable economic levels there is a higher level of discussion about the lack of money and a larger context of vulnerability, which has a great power to trigger stress and violence (Diniz et al., 2003). In this study, the couple's income was not associated with marital quality levels, which allows us to conclude that the money variable can lead to marital arguments and fights, however one wonders about its impact on the promotion of quality in the relationship.

Marital conflicts and violence are often associated with a lower educational level of the spouses, especially in common sense, but in this study it was not an influential variable on the levels of domestic violence. In this sample, most had higher education, and about $85 \%$ of couples reported suffering or having suffered some kind of violence. These data corroborate Koenig et al.'s study (2006) with the Indian population, in which education did not intervene in domestic violence. In the present study, education was not significantly different in higher levels of marital quality, which leads to the thinking that, although education promotes the exercise of dialogue and participation of both partners in the couple's decisions, providing better levels of communication and satisfaction, other variables are probably significant in this interaction (Rizzon et al., 2013).

The perception of the spouses about the levels of marital quality can be changed when they are exposed to domestic violence, which will inevitably result in suffering. Spouses perceived the violent actions of their partners as predictors of reduced marital quality. In this study, women 
felt that aggression by their partners led to the decline in the quality of the relationship and the opposite occurred with men, who perceived a lower marital quality when they reported performing some form of violence against their partners. One can ask whether the way men are raised, traditionally focused on not showing suffering, and the difficulty in recognizing the victim role impacts on this scenario, where suffered violence is less reflected in the relationship, in terms of marital quality. On the other hand, one should take into consideration how much being in the role of those who perform violence affects the well-being and quality of the marital relationship, possibly because of feelings of guilt. Women are generally accepted as victims and their suffering is socially legitimated both in the national and international contexts, thereby attributing the violence performed by their partners as factors that lower the levels of marital quality (Ackerman, 2012).

In this sample, it is noteworthy that the results of the dimensions of violence correlated with marital quality showed that the violence practices reduced the couples' perceived marital quality. Regardless of the victim or aggressor position, psychological aggression was the variable with the greatest power to predict lower marital quality in men and women. The relevance of these findings needs to be highlighted, because psychological aggression is not always legitimized by the spouses or even by professionals, due to the difficulty with its measurement, reiterating that such aggression can bring suffering and damage to the health of those involved (Colossi \& Falcke, 2013).

When the quality and violence variables are examined separately, most couples (66.54\%) evaluated their relationship as average to very good. Of these same couples, $85 \%$ reported having suffered or suffering some form of domestic violence. This information brings out the need to assess whether the method to evaluate psychological violence used was too sensitive to be present in the majority of the sample. Whereas psychological violence refers to actions such as insults, curses, screaming, among others, it is believed that even if these actions are being used by the majority of the sample, they should be considered as an occurrence of violence, so that there is no risk of naturalizing them in relationships. Because most couples somehow perceived themselves as satisfied with their relationship, it can be inferred that the naturalization of violence is already taking place. Used to this relational model, the couples end up not realizing the existence of violence in the marital relationship (Williams \& Frieze, 2005).

Evaluating the couples' perception about their relationships, particularly sensitive issues such as violence and its impact on the quality of the relationship, must cover several variables of the phenomenon. Violent practices are commonly used as an attempt, albeit inadequate, at conflict resolution. Whether practiced by men or women, it can not only have the impact of reducing marital quality, but also on the health of individuals. The results of the present study call attention to the high levels of violence and its impact on marital quality, pointing to the fact that in many relationships, the occurrence of violence seems to be naturalized, thereby becoming a common and vicious practice.
In this study, the limitations were the income and educational characteristics of the sample, which were higher than in the general population. However, this study aims to contribute to health professionals seeking intervention strategies for couples in situations of violence, because it expands the view and allows for relativizing the cases, thereby not generalizing the phenomenon but considering the individual characteristics of each couple, by showing that sometimes violence can occur more symmetrically in the relationships. Other studies with different samples and different methods, including the phenomenon of violence, can complement the evaluation, more specifically about the perception that spouses have about their relationships, as well as the interface between marital quality and domestic violence.

\section{References}

Ackerman, J. M. (2012). The relevance of relationship satisfaction and continuation to the gender symmetry debate. Journal of Interpersonal Violence, 27(18), 35793600. doi:10.1177/0886260512447579

Anacleto, A. J., Njaine, K., Longo, G. Z., Boing, A. F., \& Peres, K. G. (2009). Prevalência e fatores associados à violência entre parceiros íntimos: Um estudo de base populacional em Lages, Santa Catarina, Brasil, 2007 [Prevalence of intimate partner violence and associated factors: Apopulation-based study in Lages, Santa Catarina State, Brazil, 2007]. Cadernos de Saúde Pública, 25(4), 800-808. doi:10.1590/S0102-311X2009000400011

Bolze, S. D. A., Schmidt, B., Crepaldi, M. A., \& Vieira, M. L. (2013). Relacionamento conjugal e táticas de resolução de conflito entre casais [Marital relationship and tactics of conflict resolution between couples]. Actualidades en Psicología, 27(114), 71-85. doi:10.15517/ ap.v27i114.4828

Carvalho-Barreto, A., Bucher-Maluschke, J. S. N. F., Almeida, P. C., \& DeSouza, E. (2009). Desenvolvimento humano e violência de gênero: Uma integração bioecológica [Human development and gender violence: A bioecological integration]. Psicologia: Reflexão Crítica, 22(1), 86-92. doi:10.1590/S0102-79722009000100012

Colossi, P. M., \& Falcke, D. (2013). Gritos do silêncio: A violência psicológica no casal [Screams of silence: Psychological violence in the couple]. Psico, 44(3), 310318.

Cortez, M. B., Souza, L., \& Queiróz, S. S. (2010). Violência entre parceiros íntimos: Uma análise relacional [Intimate partner violence: A relational analysis]. Revista Psicologia Politica, 10(20), 227-243.

D’Oliveira, A. F. P. L., Schraiber, L. B., Hanada, H., \& Durand, J. (2009). Atenção integral à saúde de mulheres em situação de violência de gênero: Uma alternativa para a atenção primária em saúde [Comprehensive health (care) services to women in gender violence situation: Analternative to primary health care]. Ciência \& Saúde Coletiva, 14(4), 1037-1050. doi:10.1590/S141381232009000400011 
De Andrade, A. L., \& Garcia, A. (2012). Desenvolvimento de uma medida multidimensional para avaliação de qualidade em relacionamentos românticos - Aquarela- $R$ [Development of a multidimensional measure for quality assessment in romantic relationships - Aquarela-R]. Psicologia: Reflexão e Crítica, 25(4), 634-643. doi:10.1590/S0102-79722012000400002

DeMaris, A. (2000). Till discord do us part: The role of physical and verbal conflict in union disruption. Journal of Marriage and the Family, 62(3), 683-692. doi:10.1111/ j.1741-3737.2000.00683.x

Diniz, G. R.S. (2013). Até que a vida - ou a morte - os separe: Análise de paradoxos das relações violentas [Until life - or death - do us part: Analysis of violent relationships paradoxes]. In T. Féres-Carneiro (Ed.), Casal e família: Transmissão, conflito e violência [Couple and family: Transmission, conflict and violence] (pp. 191-216). São Paulo, SP: Casa do Psicólogo.

Diniz, N. M. F., Lopes, R. L. M., Gesteira, S. M. A., Alves, S. L. B., \& Gomes, N. P. (2003). Violência conjugal: Vivências expressas em discursos masculinos [Conjugal violence: Experiences expressed in male discourses]. Revista da Escola de Enfermagem da USP, 37(2), 81-88. doi:10.1590/S0080-62342003000200010

Falcke, D., \& Féres-Carneiro, T. (2011). Reflexões sobre a violência conjugal: Diferentes contextos, múltiplas expressões [Reflections on intimate partner violence: Different contexts and multiple expressions]. In A. Wagner (Ed.), Desafios psicossociais da família contemporânea: Pesquisas e reflexões [Psychosocial challenges of contemporary family: Research and reflections] (pp.7285). Porto Alegre, RS: Artmed.

Falcke, D., Oliveira, D. Z., Rosa, L. W., \& Bentancur, M. (2009). Violência conjugal: Um fenômeno interacional [Conjugal violence: An interactional phenomenon]. Contextos Clínicos, 2(2), 81-90.

Falcke, D., Wagner, A., \& Mosmann, C. (2013). Estratégias de resolução de conflito e violência conjugal [Strategies of conflict resolution and intimate partner violence]. In T.Féres-Carneiro (Ed.), Casal e família: Transmissão, conflito e violência [Couple and family: Transmission, conflict and violence] (pp. 159-176). São Paulo, SP: Casa do Psicólogo.

Féres-Carneiro, T., \& Diniz Neto, O. (2010). Construção e dissolução da conjugalidade: Padrões relacionais [Relational patterns of the construction and dissolution of conjugality]. Paidéia (Ribeirão Preto), 20(46), 269-278. doi:10.1590/S0103-863X2010000200014

Follingstad, D. R., \& Edmundson, M. (2010). Is psychological abuse reciprocal in intimate relationships? Data from a national sample of American adults. Journal of Family Violence, 25(5), 495-508. doi:10.1007/s10896-0109311-y

Follingstad, D. R., Rogers, M. J., \& Duvall, J. L. (2012). Factors predicting relationship satisfaction, investment, and commitment when women report high prevalence of psychological abuse. Journal of Family Violence, 27(4),

\section{7-273. doi:10.1007/s10896-012-9422-8}

Graham, J. M., Diebels, K. J., \& Barnow, Z. B. (2011). The reliability of relationship satisfaction: A reliability generalization meta-analysis. Journal of Family Psychology, 25(1), 39-48. doi:10.1037/a0022441

Hellmuth, J. C., \& McNulty, J. K. (2008). Neuroticism, marital violence, and the moderating role of stress and behavioral skills. Journal of Personality and Social Psychology, 95(1), 166-180. doi:10.1037/0022-3514.95.1.166

Hernández Sampieri, R., Fernández Collado, C., \& Baptista Lucio, M. P. (2013). Metodologia de pesquisa [Research methodology] (D. V. Moraes, Trans., 5th ed.). Porto Alegre, RS: Penso. (Original work published 1998)

Koenig, M. A., Stephenson, R., Ahmed, S., Jejeebhoy, S. J., \& Campbell, J. (2006). Individual and contextual determinants of domestic violence in North India. American Journal of Public Health, 96(1), 132-138. doi:10.2105/AJPH.2004.050872

Lamoglia, C. V. A., \& Minayo, M. C. S. (2009). Violência conjugal, um problema social e de saúde pública: Estudo em uma delegacia do interior do Estado do Rio de Janeiro [Marital violence, a social and public health problem: A study in a police station in the state of Rio de Janeiro]. Ciência \& Saúde Coletiva, 14(2), 595-604. doi:10.1590/ S1413-81232009000200028

Lawrence, E., \& Bradbury, T. N. (2007). Trajectories of change in physical aggression and marital satisfaction. Journal of Family Psychology, 21(2),236-247. doi:10.1037/08933200.21.2.236

Moraes, C. L., Hasselmann, M. H., \& Reichenheim, M. E. (2002). Adaptação transcultural para o português do instrumento "Revised Conflict Tactics Scales (CTS2)" utilizado para identificar violência entre casais [Portuguese-language cross-cultural adaptation of the Revised Conflict Tactics Scales (CTS2), an instrument used to identify violence in couples]. Cadernos de Saúde Pública, 18(1), 163-76. doi:10.1590/S0102311X2002000100017

Moreira, S. N. T., Galvão, L. L. L. F., Melo, C. O. M., \& Azevedo, G. D. (2008). Physical violence against women from the perspective of health professionals. Revista de Saúde Pública, 42(6), 1053-1059. doi:10.1590/S003489102008005000058

Mosmann, C., \& Falcke, D. (2011). Conflitos conjugais: Motivos e frequência [Marital conflicts: Causes and frequency]. Revista SPAGESP, 12(2), 5-16.

Mosmann, C., Wagner, A., \& Féres-Carneiro, T. (2006). Qualidade conjugal: Mapeando conceitos [Marital quality: Mapping out concepts]. Paidéia (Ribeirão Preto), 16(35), 315-325. doi:10.1590/S0103-863X2006000300003

Rebello, K., Junior, M. D. S., \& Brito, R. C. S. (2014). Fundamental factors in marital satisfaction: An assessment of Brazilian couples. Psychology, 5, 777-784. doi:10.4236/psych.2014.57088

Rizzon, A. L. C., Mosmann, C. P., \& Wagner, A. (2013). A qualidade conjugal e os elementos do amor: Um estudo correlacional [Marital quality and love components: A 
correlational study]. Contextos Clínicos, 6(1), 41-49. doi:10.4013/ctc.2013.61.05

Rust, J., Bennun, I., Crowe, M., \& Golombok, S. (1986). The Golombok Rust Inventory of Marital State. Sexual and Marital Therapy, 1(1), 55-60. doi: $10.1080 / 02674658608407680$

Scorsolini-Comin, F., \& Santos, M. A. (2010). Satisfação com a vida e satisfação diádica: Correlações entre construtos de bem-estar [Life satisfaction and dyadics atisfaction: Correlations between constructs of wellbeing]. Psico-USF, 15(2), 249-256. doi:10.1590/S141382712010000200012

Straus, M. A., Hamby, S. L., Boney-McCoy, S., \& Sugarman, D. B. (1996). The revised Conflict Tactics Scales (CTS2): Development and preliminary psychometric data. Journal of Family Issues, 17(3), 283-316. doi: $10.1177 / 019251396017003001$

Testa, M., \& Leonard, K. E. (2001).The impact of marital aggression on women's psychological and marital functioning in a newlywed sample. Journal of Family Violence, 16(2), 115-130. doi:10.1023/A:1011154818394

Vieira, E. M., Perdona, G. S. C., \& Santos, M. A. (2011). Fatores associados à violência física por parceiro íntimo em usuárias de serviços de saúde [Factors associated with intimate partner physical violence among health service users]. Revista de Saúde Pública, 45(4), 730-737. doi:10.1590/S0034-89102011005000034

Williams, S. L., \& Frieze, I. H. (2005). Patterns of violent relationships, psychological distress, and marital satisfaction in a national sample of men and women. Sex Roles, 52(11-12), 771-784. doi:10.1007/s11199-0054198-4

Josiane Razera is a Ph.D. candidate in the Graduate Psychology Program at Universidade do Vale do Rio dos Sinos - UNISINOS.

Clarisse Pereira Mosmann is a Professor at Universidade do Vale do Rio dos Sinos - UNISINOS.

Denise Falcke is a Professor at Universidade do Vale do Rio dos Sinos - UNISINOS.

Received: Jan. 16, 2015

1st Revision: Apr. 26, 2015

Approved: June 11, 2015

How to cite this article:

Razera, J., Mosmann, C. P., \& Falcke, D. (2016). The interface between quality and violence in marital relationships. Paidéia (Ribeirão Preto), 26(63), 71-79. doi:10.1590/1982-43272663201609 